PERNIK Jurnal PAUD, VOL 3 NO. 1 September 2020

\title{
STRATEGI PEMBELAJARAN BAHASA INGGRIS DI TINGKAT DASAR
}

\author{
Yuspar Uzer M.Pd \\ Email:yusparuzer@gmail.com \\ Universitas PGRI Palembang
}

\begin{abstract}
Abstrak:Strategi adalah pola kegiatan pembelajaran yang dipilih dan digunakan guru secara kontekstual, sesuai dengan karakteristik siswa, kondisi sekolah, lingkungan sekitar serta tujuan khusus pembelajaran yang adalah perlu adanya kaitan antara strategi pembelajaran dengan tujuan pembelajaran, agar diperoleh langkah-langkah kegiatan pembelajaran yang efektif dan efisien. Strategy pembelajaran terdiri dari metode dan teknik (prosedur) yang akan menjamin bahwa siswaakan betul-betul mencapai tujuan pembelajaran. Banyak peneliti yang mengelompokkan strategi belajar menjadi 4 jenis: kognitif, meta-kognitif, efektif, dan sosial. Strategi kognitif berhubungan dengan daya pikir pembelajar dalam emngolah bahan belajar mengajar. Strategi meta-kognitif berhubungan dengan taktik atau cara pembelajar untuk menghadapi dan mengelola bahan belajar mengjar. Strategi efektif berhubungan dengan sikap dan perasaan pembelajar dalam menghadapi proses belajar pembelajar. Strategi sosial berhubungan dengan kerjasama pembelajar dengan sejawatnya dalam mencapai tujuan belajar.Pengelompokkan ini tampaknya lebih sederhana namun lebih jelas batasanbatasannya. Sedangkan menurut Oxford memiliki pikiran-pikiran dasar yang sama seperti beberapa peneliti lain, Oxford pertamatama membagi strategi belajar menjadi dua bagian besar: langsung dan tidak langsung. Starategi langsung kemudian dirinci lebih lanjut menjadi tiga jenis; memori, kognitif, dan kompensasi. Strategi tidak langsung dibagi menjadi tiga: meta-cognitif, efektif, dan social. Masing-masing strategi memiliki jenis-jenis kegiatan sendiri. Menurut Burdo \& Byrd mengemukakan beberapa strategi yang dapat dipilih guru dalam pembelajaran, yaitu strategi Deduktif-Induktif dan strategi Ekspositori langsung dan belajar tuntas
\end{abstract}

Kata Kunci: strategi, pembelajaran bahasa inggris, tingkat dasar

\section{PENDAHULUAN}

Paradigma pembelajaran bahasa

telah mengalami pergeseran sejak terjadinya perubahan Kurikulum 1984 ke Kurikulum 1994 yang lalu.Pergeseran itu ditandai dengan berubahnya orientasi pembelajaran pada saat diberlakukannya Kurikulum 1984.

Ketika Kurikulum 1984 diberlakukan, pembelajaran berfokus pada penguasaan halhal yang bersifat gramatikal. Sementara itu, Kurikulum 1994 yang diganti menjadi Kurikulum 2004 dan kemudian disempurnakan menjadi Kurikulum 2006 menghendaki pembelajaran berorientasi pada pengembangan 4 keterampilan berbahasa, yaitu: mendengarkan (listening), membaca (reading), berbicara (speaking), dan menulis (writing). Orientasi pembelajaran pada keempat keterampilan tersebut bertujuan untuk meningkatkan kemampuan siswa berkomunikasi baik lisan maupun tulisan.Akan tetapi, keadaan pembelajaran bahasa Inggris di sekolahsekolah tidak membawa siswa ke arah pencapaian kemahiran berbahasa tersebut.

Menurut Sumardi (di dalam Sumardi, 1992: 206) di dalam proses pembelajaran, guru lebih mendominasi 
pembelajaran. Guru lebih banyak memberikan bekal berupa teori dan pengetahuan bahasa daripada mengutamakan keterampilan berbahasa baik lisan maupun tulisan.

Maksan (dalam Sutama, 1998) mengemukakan bahwa siswa belum dapat dikatakan mampu berbahasa (Inggris) secara baik dan benar, baik lisan maupun tulisan, pada setiap jenjang sekolah, mulai dari SD sampai dengan SMA.Selain itu, Alwi mengatakan (1999: 1) "Berbicara mengenai mutu pembelajaran bahasa sekarang ini, secara jujur kita katakan bahwa mutunya masih rendah.

"Berbagai faktor menjadi penyebab siswa gagal termasuk gagal dalam UN tersebut.Seperti rendahnya minat siswa untuk belajar bahasa Inggris.Banyak siswa yang tidak memiliki motivasi untuk belajar bahasa Inggris. Pengajaran bahasa dapat berhasil dengan baik apabila terdapat pengetahuan yang cukup terhadap sifat-sifat dan prilaku pembelajar. Dalam suatu proses belajar mengajar, selalu ada pembelajar yang berhasil dengan baik dan pembelajar yang kurang berhasil. Hal ini disebabkan oleh berbagai factor, salah satunya adalah cara atau strategi belajar orang yang belajar tersebut. Dalam hal ini, Naiman dkk, (1978:
1) menyatakan bahwa "Semua bentuk pengajaran bahasa dapat dikembangkan dengan baik apabila kita memiliki pengetahuan yang cukup tentang pembelajaran dan proses belajar mengajar itu sendiri. Dengan demikian, pengetahuan mengenai sifat-sifat pembelajar akan membantu dalam memfasilitasi kegiatan belajar mengajar sehingga pembelajar dapat mencapai hasil yang maksimal.

Bahasa Inggris merupakan salah satu di antara bahasa asing yang terdapat di Indonesia. Bahasa Inggris ditetapkan sebagai bahasa asing yang pertama sesuai dengan surat keputusan Menteri Pendidikan dan Kebudayaan No. 096/1967 tanggal 12 Desember 1967 (Kartono, 1980: 126).

Terpilihnya Bahasa Inggris sebagai bahasa asing pertama di Indonesia di antara bahasa asing lainnya didasarkan pada beberapa pertimbangan seperti yang diutarakan Kartono (1980: 125) bahwa bahasa nasional kita pada saat ini belum dapat dipakai sebagai alat komunikasi dengan dunia luar dalam rangka politik luar negeri dan untuk menjalin persahabatan dengan bangsa-bangsa lain, dan kenyataan bahwa bahasa Inggris adalah bahasa komunikasi internasional, bahasa ilmu pengetahuan, teknologi modern, 
perdagangan, politik, dan dipakai hampir disemua bidang, maka bahasa Inggris jelas harus diberi prioritas pertama untuk dipelajari di antara bahasa-bahasa asing yang lain. Peran bahasa Inggris di atas akan dapat tercapai apabila sistem pendidikan berlangsung dengan baik, sebab pendidikan

Pembelajaran adalah kegiatan yang di dalamnya terdapat proses mengajar, membimbing, melatih, memberi contoh, dan mengatur serta memfasilitasi berbagai hal kepada peserta didik agar biasa belajar sehingga tercapai tujuan pendidikan. Pembelajaran merupakan suatu proses interaksi yang dilakukan pendidik kepada peserta didik untuk memunculkan keinginan belajar dan mencapai tujuan yang telah ditetapkan melalui media, lingkungan, dan lainnya.

Strategi pembelajaran bahasa inggris memainkan peranan yang sangat penting di dalam kegiatan belajar bahasa Inggris. Ada banyak siswa yang mampu mencapai prestasi baik karena diajarkan menggunakan metode pembelajaran bahasa inggris yang tepat.Sebuah metode pembelajaran bahasa Inggris merupakan kunci dalam pembelajaran.Apabila seorang guru menerapkan metode yang kurang tepat serta membosankan, maka habislah sudah kelas tersebut. Rata-rata, siswa akan cenderung bosan dan tidak menyukai kelas bahasa Inggris yang berlangsung selama hampir dua jam.

\section{PEMBAHASAN}

\section{Konsep Pengajaran Bahasa (Asing)}

Konsep pengajaran bahasa (asing) tidak terlepas dari konsep belajar itu sendiri.Semakin baiknya pemahaman terhadap hakikat perkembangan anak telah melahirkan pandangan konstruktivisme dalam pembelajaran. Terkait dengan belajar bahasa, hal terpenting yang harus dipahami adalah bahwa belajar bahasa adalah suatu proses akuisisi dengan tujuan tercapainya kemampuan berkomunikasi.

Teori pembelajaran bahasa kedua (SLA Theory) menunjukkan bahwa seorang anak belajar karena adanya kebutuhan untuk itu, dan mereka dapat memenuhinya melalui belajar bahasa. Teori itu juga mengatakan bahwa kemampuan berbahasa berkembang secara bertahap dari yang mudah ke yang lebih kompleks. Dengan memperhatikan ciri-ciri perkembangan kemampuan berbahasa anak, maka pengajaran bahasa mesti dilakukan dengan memperhatikan konsep-konsep berikut: a. Guru sebagai model. 
b. Hadirkan situasi alamiah dimana penggunaan bahasa Inggris sebagai bahasa sehari- hari c. Hadirkan baha Inggris sebagai bahasa, bukan sebagai pelajaran yang tak berguna d. Kesalahan yang dibuat anak bukan merupakan suatu kegagalan, melainkan menunjukkan bahwa dia sedang berkembang e. Fokuskan lebih pada makna, bukan pada bentuk bahasa f. Lakukan komunikasi, meski dengan kalimat-kalimat yang sangat sederhana, dan jawaban siswa pun mungkin sepatah-sepatah g. Aturan (tata bahasa/grammar) memang penting, tetapi pada tahap awal, hindarkan mengajarkan tata bahasa secara eksplisit/langsung untuk menghindarkan frustrasi pada anak

\section{Jenis-jenis Strategi pembelajaran Bahasa Inggris}

Strategi belajar memiliki beberapa sifat. Naiman, dkk (1978: 3) mengemukakan 10 jenis strategi belajar yang bersumber dari Stern (1975): rencana, aktif, empatik, formal, eksperimental, semantik, latihan, komunikatif, pantau dan pengahayatan. Pengelompokkan ini tampaknya dapat meliput banyak yang terjadi dalam proses belajar mengajar. Namun, sebagaimana dinyatakan oleh Stern sendiri, jenis-jenis strategi ini masih bersifat sementara dan memerlukan konfirmasi dan modifikasi.
Misalnya, beberapa kelompok tersebut masih terkesan tumpang tindih. Beberapa sifat dalam strategi rencana menyerupai sifat strategi pantau. Demikian strategi formal dan strategi latihan. Banyak peneliti yang mengelompokkan strategi belajar menjadi 4 jenis: kognitif, meta-kognitif, efektif, dan sosial (O’Malley dan Chamot, 1990; Cohen, 1990; Oxford, 1990).

Strategi kognitif berhubungan dengan daya pikir pembelajar dalam mengolah bahan belajar mengajar. Strategi meta-kognitif berhubungan dengan taktik atau cara pembelajar untuk menghadapi dan mengelola bahan belajar mengjar. Strategi efektif berhubungan dengan sikap dan perasaan pembelajar dalam menghadapi proses belajar pembelajar. Strategi sosial berhubungan dengan kerjasama pembelajar dengan sejawatnya dalam mencapai tujuan belajar. Pengelompokkan ini tampaknya lebih sederhana, namun lebih jelas batasanbatasannya.

Oxford (1990) membagi strategi belajar menjadi dua bagian besar: langsung dan tidak langsung. Strategi langsung kemudian dirinci lebih lanjut menjadi tiga jenis; memori, kognitif, dan kompensasi. Strategi tidak langsung dibagi menjadi tiga: meta-kognitif, efektif, dan sosial. Masing- 
masing strategi memiliki jenisjenis kegiatan strategi tersebut beserta jenis kegiatannya. sendiri. Diagram 1 menunjukkan jenis

Diagram 1. Menunjukkan jenis strategi tersebut beserta jenis kegiatannya.



a. Memori Strategi belajar memori digunakan oleh pembelajar dengan memanfaatkan pengetahuan dan pengalaman belajar sebelumnya. Strategi belajar ini banyak melibatkan ingatan dan proses pembelajaran yang menggunakan daya ingat. Misalnya, apabila pembelajar menghubungkan bunyi ujaran dengan halhal yang pernah diingatnya, maka ia sedang menggunakan strategi belajar memori. Termasuk dalam strategi belajar ini adalah mengulang pelajaran sebelumnya. Demikian pula, apabila pembelajar menggunakan gerakan-gerakan badan untuk mmbantu pemahaman, maka ia sedang mempraktikkan strategi belajar memori. 
b. Kognitif Strategi kognitif adalah segala perilaku pembelajar dalam proses belajar mengajar yang behubungan dengan penggunaan daya pikir pembelajar. Strategi ini dapat berwujud berbagai kegiatan. Dalam suatu penelitan, ditentukan enam macam perilaku kognitif yang diharapkan dapat mewakili strategi ini. Keenam perilaku inin adalah: membetulkan kesalahan sendiri, menggunakan gerakan isyarat, melatih mengucapkan kata, menulis dalam buku catatan, membaca dari papan tulis, dan menatap media ajar.

\section{c. Kompensasi Strategi belajar} konpensasi digunakan oleh pembelajar yang telah memiliki keterampilan- keterampilan yang cukup tinggi.

\section{Strategi belajar ini biasanya dimanfaatkan untuk menanggulangi beberapa keterbatasan dalam berbahasa.} Pembelajar yang mengalami kesulitan dalam menerangkan sesuatu dalam bahasa yang dipelajari, misalnya dapat menggunakan definisi atau terjemahan dalam ujarnya untuk menjaga agar proses berbahasa tetap berjalan. Bahkan, gerakan-gerakan badan dapat digunakan untuk menutup keterbatasan yang ia hadapi. Termasuk dalam jenis strategi belajar ini adalah menentukan atau memilih sendri topik yang dibicarakan. Bahkan untuk menghindari topik yang sulit juga merupakan strategi dalam kelompok ini.

d. Meta-kognitif Strategi metakognitif adalah segala perilaku pembelajar yang berhubungan dengan teknik atau cara pembelajar untuk menghadapi dan mengelola bahan belajar mengajar. Dalam penelitian ini, strategi meta-kognitif diwujudkan berbagai macam kegiatan yang dapat dimasukan ke dalam tiga kategori berikut: memutuskan perhatian merencanakan dan menyusun kegiatan belajar mengajar, dan mengevaluasi proses belajar mengajar.

Dapat ditekankan bahwa semua ini harus datang dari dan dikerjakan oleh pembelajar.e. Afektif Strategi afektif adalah segala perilaku pembelajar yang berhubungan dengan sikap dan perasaan pembelajar dalam menghadapi proses belajar. Strategi ini lebih lanjut dibagi menjadi dua: afektif positif dan afektif negatif.

Strategi afektif positif adalah prilaku pembelajar yang menunjukkan bahwa pembelajar menerima dan menghargai proses belajar mengajar. Strategi afektif negatif adalah prilaku pembelajar yang menunjukkan bahwa pembelajar menolak 
dan tidak menghargai proses belajar mengajar. Perlu diperhatikan bahwa istilah "negatif" sebagaimana digunakan di sini tidak mengandung makna jelek atau buruk. Penolakan pembelajar tehadap proses belajar mengajar harus dipandang sebagai sikap yang "netral",yang tidak berhubungan dengan nilai baik-buruk.

Strategi afektif positif diwakili oleh empat prilaku: tertawa dengan menunjukkan kesenangan atau kepuasan, tersenyum menunjukkan kepuasan dan menunjukkan kesenangan karena hal-hal yang lucu menyenangkan. Strategi afektif negatif diwakili oleh lima perilaku: menunjukkan kebingungan, mengeluh, tidak memperhatikan guru, berbicara dengan teman sebangku di luar relavansi belajar, dan menunjukkan sikap masa bodoh. f. Sosial Strategi sosial adalah segala perilaku pembelajar yang berhubungan dengan kerja sama pembelajar dengan sejawatnya dalam mencapai tujuan belajar.

Strategi ini diwujudkan dalam enam kegiatan: berbicara dengan teman sebangku mengenai pelajara, membantu teman sesuai dengan kegiatan belajar mengajar, minta bantuan kepada teman, memberikan pujian kepada teman, melecehkan atau menyoraki teman dan mengganggu teman.
Menurut Richards $\mathrm{J}$ dalam bukunya Approaches and Methods in Language Teaching, TPR didefinisikan suatu metode pembelajaran bahasa yang disusun pada koordinasi perintah (command), ucapan (speech) dan gerak (action); dan berusaha untuk mengajarkan bahasa melalui aktivitas fisik (motor).

Sedangkan menurut Larsen dan Diane dalam Technique and Principles in Language Teaching, TPR atau disebut juga "the comprehension approach" atau pendekatan pemahaman yaitu suatu metode pendekatan bahasa asing dengan instruksi atau perintah. Metode ini dikembangkan oleh seorang professor psikologi di Universitas San Jose California yang bernama Prof. Dr. James J. Asher yang telah sukses dalam pengembangan metode ini pada pembelajaran bahasa asing pada anakanak.

Ia berpendapat bahwa pengucapan langsung pada anak atau siswa mengandung suatu perintah, dan selanjutnya anak atau siswa akan merespon kepada fisiknya sebelum mereka memulai untuk menghasilkan respon verbal atau ucapan. Metode TPR ini sangat mudah dan ringan dalam segi penggunaan bahasa dan juga mengandung unsur gerakan permainan 
PERNIK Jurnal PAUD, VOL 3 NO. 1 September 2020

sehingga dapat menghilangkan stress pada peserta didik karena masalah-masalah yang dihadapi dalam pelajarannya terutama pada saat mempelajari bahasa asing, dan juga dapat menciptakan suasana hati yang positif pada peserta didik yang dapat memfasilitasi pembelajaran sehingga dapat meningkatkan motivasi dan prestasi siswa dalam pelajaran tersebut.

Makna atau arti dari bahasa sasaran dipelajari selama melakukan aksi. Guru memiliki peran aktif dan langsung dalam menerapkan metode TPR ini. Menurut Asher "The instructor is the director of a stage play in which the students are the actors", yang berarti bahwa guru (instruktur) adalah sutradara dalam pertunjukan cerita dan di dalamnya siswa sebagai pelaku atau pemerannya.

Guru yang memutuskan tentang apa yang akan dipelajari, siapa yang memerankan dan menampilkan materi pelajaran. Siswa dalam TPR mempunyai peran utama sebagai pendengar dan pelaku.Siswa mendengarkan dengan penuh perhatian dan merespon secara fisik pada perintah yang diberikan guru baik secara individu maupun kelompok.

\section{KESIMPULAN}

Kesimpulan Strategi adalah pola kegiatan pembelajaran yang dipilih dan digunakan guru secara kontekstual, sesuai dengan karakteristik siswa, kondisi sekolah, lingkungan sekitar serta tujuan khusus pembelajaran yang adalah perlu adanya kaitan antara strategi pembelajaran dengan tujuan pembelajaran, agar diperoleh langkah-langkah kegiatan pembelajaran yang efektif dan efisien. Strategy pembelajaran terdiri dari metode dan teknik (prosedur) yang akan menjamin bahwa siswaakan betul-betul mencapai tujuan pembelajaran.

Banyak peneliti yang mengelompokkan strategi belajar menjadi 4 jenis: kognitif, meta-kognitif, efektif, dan sosial. Strategi kognitif berhubungan dengan daya pikir pembelajar dalam emngolah bahan belajar mengajar. Strategi metakognitif berhubungan dengan taktik atau cara pembelajar untuk menghadapi dan mengelola bahan belajar mengjar. Strategi efektif berhubungan dengan sikap dan perasaan pembelajar dalam menghadapi proses belajar pembelajar.

Strategi sosial berhubungan dengan kerjasama pembelajar dengan sejawatnya dalam mencapai tujuan belajar. 
Pengelompokkan ini tampaknya lebih sederhana namun lebih jelas batasanbatasannya. Sedangkan menurut Oxford memiliki pikiran-pikiran dasar yang sama seperti beberapa peneliti lain, Oxford pertamatama membagi strategi belajar menjadi dua bagian besar: langsung dan tidak langsung. Starategi langsung kemudian dirinci lebih lanjut menjadi tiga jenis; memori, kognitif, dan kompensasi. Strategi tidak langsung dibagi menjadi tiga: metacognitif, efektif, dan social. Masing-masing strategi memiliki jenis-jenis kegiatan sendiri. Menurut Burdo \& Byrd mengemukakan beberapa strategi yang dapat dipilih guru dalam pembelajaran, yaitu strategi Deduktif-Induktif dan strategi Ekspositori langsung dan belajar tuntas.

Kita tidak ingin terjadi hal yang sebaliknya, justru siswa sudah antipati

\section{DAFTAR PUSTAKA}

Confrey, Jere. (1995). 'A Theory of Intellectual Development'.Journal for the Learning of Mathematics. Vol 15,1 (Februari). 38 - 47.

Edelsky, C., Altwelger, B., \& Flores, B. (1991). Whole Language What's the Difference?. N.H.: Heinemann.

Goodman, K. (1986) What's Whole in Whole Language, New Hampshire: Heinemann. dengan bahasa Inggris sejak dari SD, yang disebabkan oleh pengalaman belajar yang tidak menyenangkan ketika di SD.

Penulis mengharapkan kepada pendidik dan peserta didik untuk dapat sadar dan memahami serta berupaya untuk dapat meningkatkan kualitas pengetahuan terhadap pembelajaran Bahasa Inggris dengan cara yang menyenangkan dan mudah dipahami, selalu memberikan yang terbaik sesuai dengan yang telah ditetapkan Adapun saran kami adalah selayaknya guru bisa menentukan metode sebelum pembalajaran bahasa Inggris, karena dengan begitu guru bisa mengevaluasi hasil dari pembelajaran tersebut. Karena metode merupakan serangkaian proses dari awal sampai akhir pembelajaran. Karena itulah metode dalam sebuah pembelajaran sangat penting bagi seorangguru.

Krashen, S.D. (1999). Principles and Practice in Second Language Acquisition. Englewood Cliffs, N.J. : Prentice-Hall International.

Spada, N \& Lightbown, P.M. (1993). How Languages Are Learned. Oxford: Oxford Univ. Press.

Kulik, C. C., Kulik, J.A. \& BangertDrowns, R.L. (1990). 'Effectiveness of Mastery learning Programs: A MetaAnalisis'. Review of Educational 
Research. Vol. 60, No. 2, Summer, pp. 265-299.

Lado, R. (1985). Memory Span as a Factor in Second Language Learning, dalam IRAL 3:23-129.

Nunan, D. (1990). Designing Tasks for Communicative Classroom. Cambridge: Cambridge University Press.

Oxford, R. L. (1990). Language Learning Strategies: What Every Teacher Should Know. Boston: Heinle and Heinle Publishers.

O'Malley, J. M., \& A. Chamot.(1990). Learning Strategies in Second Language Acquisition. Cambridge: Cambridge University Press.

Stern, H.H. (1983). Fundamental Concepts Of Language Teaching. 7th Impression. Oxford: Oxford University Press.

Wina Sanjaya. (2006). Strategi Pembelajaran Berorientasi Standar Proses Pendidikan. Jakarta: Prenada Media Group. 